\title{
Клінічний випадок тяжкої двобічної пневмонії, асоційованої з вірусною інфекцією SARS-CoV-2
}

\author{
О.А. Боришевська-Логін, В.І. Агій, Ю.Ю. Переста, С.Й. Акар, О.Л. Логойда, Н.П. Ганбаров
}

Товариство з обмеженою відповідальністю «Медичний центр «Діамед», Ужгород, Україна

Анотація. Коронавірусна інфекція стрімко поширюється і передається від людини до людини повітряно-краплинним та контактнопобутовим шляхом. Для остаточного діагнозу необхідний позитивний тест полімеразно-ланцюгової реакції (ПЛP) на SARS-CoV-2. Tим не менше мультиспіральна комп'ютерна томографія (МСКТ) є чутливим та специфічним методом діагностики коронавірусного ураження легень як найбільш частого прояву інфекції. Крім того, у пацієнтів із високим ризиком COVID-19 ознаки вірусної пневмонії при MCKT легень можуть передувати негативним результатам ПЛР-тесту. На власному досвіді та спостереженнях у діагностиці тяжкого респіраторного синдрому SARS-CoV-2 привертаємо увагу до необхідності виконання МСКТ органів грудної клітки у пацієнтів із високим ризиком та клінічними проявами COVID-19-асоційованої пневмонії, незважаючи на первинні негативні результати ПлР-тесту.

Ключові слова: SARS-CoV-2, COVID-19, коронавірусна інфекція, ураження легень, ПЛР-тестування, МСКТ органів грудної клітки.

Коронавірусна хвороба COVID-19 - досить нова легенева вірусна інфекція, викликана коронавірусом тяжкого респіраторного синдрому SARS-CoV-2.

Коронавірусна інфекція стрімко поширюється і передається від людини до людини повітряно-краплинним та контактно-побутовим шляхом; призводить до тяжких ускладнень, таких як запалення та фіброз легень, гостра дихальна та серцева недостатність, дисфункція згортальної системи крові, а також до тяжкого міокардиту та геморагічної некротичної енцефалопатії з переважним ураженням таламічних зон [1].

Для остаточного діагнозу необхідний позитивний тест полімеразно-ланцюгової реакції (ПЛР) на SARS-CoV-2. Тим не менше мультиспіральна комп'ютерна томографія (МСКТ) є чутливим та специфічним методом діагностики коронавірусного ураження легень як найчастішого прояву інфекції. Метод підходить як для первинної діагностики, так і для спостереження за станом пацієнтів у динаміці лікування та раннього виявлення ускладнень (приєднання бактеріальної пневмонії, тромбоемболії легеневої артерії тощо), моніторування еволюції останніх. Крім того, у пацієнтів із високим ризиком COVID-19 ознаки вірусної пневмонії при МСКТ легень можуть передувати негативним результатам ПЛР-тесту, а отже, водночас стати вагомим аргументом для виконання повторного лабораторного тестування на SARS-CoV-2 [2].

Наводимо клінічне спостереження, виконане на базі нашої клініки.

\section{Клінічний випадок}

Пацієнт 3., 64 роки. Звернувся зі скаргами на підвищення температури тіла до $38,5^{\circ} \mathrm{C}$ протягом останніх 5 днів, малопродуктивний кашель, загальну слабкість, задишку. В анамнезі контакт із інфікованими SARS-CoV-2. Оксигенація крові в день звернення 94-95\%. Первинний ПЛР-тест негативний. Стан паці$\epsilon$ нта сімейним лікарем оцінено як задовільний. Попередній діагноз - гостра респіраторна вірусна інфекція.

При огляді в клініці: підвищене потовиділення, постійне покашлювання, в'ялість. При фізикальному обстеженні: дихання жорстке з обох боків, більше справа, тахіпное, тахікардія (110 уд./хв).

При лабораторному обстеженні: зниження кількості лімфоцитів та тромбоцитів, підвищення кількості моноцитів та швидкості осідання еритроцитів, незначна анемія, підвищення рівня D-димеру.

На МСКТ органів грудної клітки (рис. 1, 2): двобічні несиметричні зливного характеру ділянки патологічного ураження у вигляді «матового скла» 3 нашаруванням потовщених внутрішньолобулярних та міжлобулярних перетинок («paving stone») [3].
Рисунок 1 МСКТ органів грудної клітки пацієнта 3. в аксіальній площині. Стрілкою вказані ділянки патологічного ураження легеневої паренхіми у вигляді «матового скла»

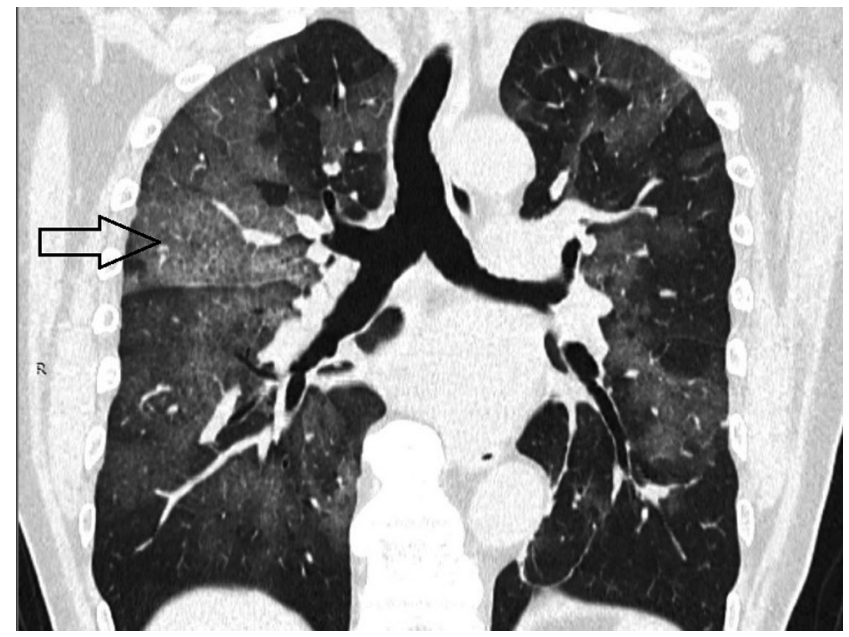

Рисунок 2 МСКТ органів грудної клітки пацієнта 3. у коронарній площині. Стрілкою вказані ділянки ураження легеневої паренхіми («paving stone»)

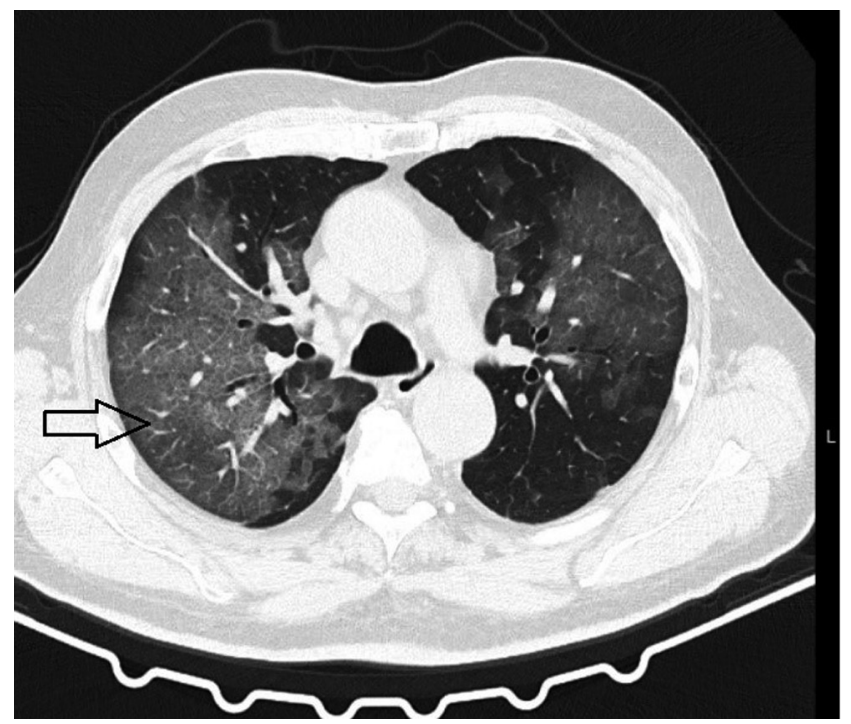


На основі візуалізаційних, лабораторних, фізикальних та анамнестичних даних встановлено діагноз «Гостра двобічна вірусна пневмонія, найвірогідніше асоційована з SARS-CoV-2».

Наступного дня виконано повторний ПЛР-тест з отриманням позитивного результату.

Пацієнт направлений у профільне відділення районної лікарні для проходження стаціонарного лікування. На жаль, стан пацієнта різко погіршувався за рахунок наростання явищ дихального дистрес-синдрому, що призвело до летального наслідку.

Вищенаведений клінічний випадок підкреслює необхідність мультидисциплінарного (клінічного, лабораторного, радіологічного) підходу в обстеженні пацієнтів із вірогідною вірусною пневмонією середнього та тяжкого ступеня. Це необхідно для своєчасної верифікації діагнозу та ефективного патогномонічного лікування з метою зниження летальності, попередження ускладнень, скорочення часу стаціонарного лікування та за необхідності - реабілітаційного періоду.

Запропонована нами методика обстеження полягає в оптимізації протоколу сканування при комп'ютерній томографії високого розрішення (High-resolution computed tomography HRCT) на апараті «SOMATOM go.Up»» («Siemens», Німеччина) 2019 р., виконаного за наступним протоколом:

- фронтальне сканування топограми [Tr20] довжиною 512 мм 3 індивідуальним підбором та корекцією параметрів Kv; Effective mAs, застосовуючи технологію CARE Dose4D з обчисленням оптимального Quality Reference mAs (QRM) для кожної кутової проєкції анатомічної ділянки пацієнта;

- нативне (безконтрастне) сканування органів грудної клітки на затримці дихання із застосуванням протоколу: Low Dose and Fast Scan in a Patient with Dyspnea (Collimation: $32 \cdot 0,7 \mathrm{~mm}$, Rotation time: $0,8 \mathrm{~s}$, Pitch factor: 1,5 , Scan parameters: Sn 110 (with Tin Filter) kV/60 mAs, Scan time: 9 s). Алгоритм реконструкції SAFIRE [1,5 mm жорсткість фільтраціїbr 40 (Soft); $\mathrm{Br}$ - 60 (lung)]. Постпроцесингова обробка зображень MPR-; MIP, MinIP, Avg [3].

Такий протокол сканування при МСКТ-дослідженні забезпечує підвищення точності діагностики характерних для COVID-19 ранніх рентгенологічних ознак, а також дозволяє зменшити променеве навантаження на пацієнта.

Таким чином, власний досвід та спостереження у діагностиці тяжкого респіраторного синдрому SARS-CoV-2 свідчать про необхідність виконання МСКТ органів грудної клітки у пацієнтів із високим ризиком та клінічними проявами COVID-19асоційованої пневмонії, незважаючи на первинні негативні результати ПЛР-тесту [4].

\footnotetext{
Відомості про авторів:

Боришевська-Логін Олена Анатоліївна — лікар-рентгенолог ТОВ «Медичний центр «Діамед», Ужгород, Україна. ORCID ID: 0000-0001-5861-7300

Агій Владислава Іванівна — кандидат медичних наук, лікар-рентгенолог ТОВ «Медичний центр «Діамед», Ужгород, Україна. ORCID ID: 0000-0003-0677-7278

Переста Юрій Юрійович — доктор медичних наук, професор, лікар-хірург ТОВ «Медичний центр «Діамед», Ужгород, Україна. ORCID ID: 0000-0003-1479-4289

Акар Станіслав Йосипович — лікар-радіолог ТОВ «Медичний центр «Діамед», Ужгород, Україна. ORCID ID: 0000-0003-4159-5939

Логойда Ольга Любомирівна — лікар-рентгенолог ТОВ «Медичний центр «Діамед», Ужгород, Україна. ORCID ID: 0000-0003-1249-5752

Ганбаров Нікіта Петрович — студент V курсу Національного медичного університету імені 0.0. Богомольця, Київ, Україна. ORCID ID: 0000-0001-8165-5356

Адреса для кореспонденції:

Логойда Ольга Любомирівна

88000 , Ужгород, вул. Швабська, 43

E-mail: logoyda.o@gmail.com
}

Інформація про внесок кожного учасника у підготовку статті

Автори заявляють про однаковий внесок кожного з них у підготовку статті.

\section{Фінансування}

Дослідження та написання статті фінансовано ТОВ «Медичний центр «Діамед» (Ужгород, Україна).

Конфлікт інтересів: відсутній.

Conflict of interests: the authors declare no conflict of interests.

\section{Список використаної літератури/References:}

1. Carotti M., Salaffi F., Sarzi-Puttini P. (2020) Chest CT features of coronavirus disease 2019 (COVID-19) pneumonia: key points for radiologists. Radiol. Med., 125: 636-646. https://doi. org/10.1007/s11547-020-01237-4

2. Kwee Th.C., Kwee R.M. (2020) Chest CT in COVID-19: What the Radiologist Needs to Know. Radiographics, 40(7): 1848-1865. doi: 10.1148/rg.2020200159

3. Boryshevska-Lohin 0.A., Ahii V.I., Akar S.I. et al. (2020) Method for diagnosing COVID-19 pneumonia. Patent № 145093. [In Ukr.].

4. Lee E.Y.P., Ng M.-Y., Khonga P.-L. (2020) COVID-19 pneumonia: what has CT taught us? Lancet Infect. Dis., 20(4):384-385. https://doi.org/10.1016/S1473-3099(20)30134-1

\section{Clinical case of severe bilateral pneumonia associated with SARS-CoV-2 viral infection}

\section{O.A. Boryshevska-Lohin, V.I. Ahii, Yu.Yu. Peresta, S.Y. Akar,} O.L. Lohoida, N.P. Hanbarov

Diamed Medical Center, Uzhhorod, Ukraine

Abstract. Coronavirus infection spreads rapidly and is transmitted from person to person by airborne and contact-household routes. A positive polymerase chain reaction (PCR) test for SARS-CoV-2 is required for a definitive diagnosis. However, multi-slice computed tomography (MSCT) is a sensitive and specific method of diagnosing coronavirus lung disease as the most common manifestation of infection. In addition, in patients at high risk of COVID-19, signs of viral pneumonia in MSCT of the lungs may precede negative PCR results. Based on our own experience and observations in the diagnosis of severe respiratory syndrome SARS-CoV-2, we draw attention to the need to perform MSCT of the chest in patients at high risk and clinical manifestations of COVID-19-associated pneumonia, despite the initial negative PCR result. Key words: SARS-CoV-2, COVID-19, coronavirus infection, lung lesions, PCR-testing, MSCT of chest organs.

\section{Information about the authors:}

Boryshevska-Lohin Olena A. — MD, radiologist, Diamed Medical Centre, Uzhhorod, Ukraine. ORCID ID: 0000-0001-5861-7300

Ahii Vladyslava I. — MD, PhD (Med.), radiologist, Diamed Medical Centre, Uzhhorod, Ukraine. ORCID ID: 0000-0003-0677-7278

Peresta Yurii Yu. — MD, surgeon, Doctor of Medical Science, Professor, Diamed Medical Centre, Uzhhorod, Ukraine. ORCID ID: 0000-0003-1479-4289

Akar Stanislav Y. — MD, radiologist, Diamed Medical Centre, Uzhhorod, Ukraine. ORCID ID: 00000003-4159-5939

Lohoida Olha L. — MD, radiologist, Diamed Medical Centre, Uzhhorod, Ukraine. ORCID ID: 00000003-1249-5752

Hanbarov Nikita P. - 5th year student of 0.0. Bogomolets National Medical University, Kyiv, Ukraine. ORCID ID: 0000-0001-8165-5356

Address for correspondence:

Olha Lohoida

88000, Uzhhorod, Shvabska str., 43

E-mail: logoyda.o@gmail.com 